\title{
USE OF INFORMATION AND COMMUNICATION TECHNOLOGIES IN INDIA'S FIRST OPEN UNIVERSITY: Experience and Perceptions of Learners and Learner Support Providers
}

\author{
Dr. P. SATYANARAYANA \\ Indira Gandhi National Open University \\ Hyderabad, INDIA
}

Prof. Dr. Emmanuel DK MEDURI Teegala Krishna Reddy Engineering College

Hyderabad, INDIA

\section{ABSTRACT}

Dr. B.R. Ambedkar Open University (BRAOU), the first distance teaching university in India, was a great educational event. It started a new chapter in the history of India's distance higher education. The general objects these research studies are:

- to identify the information and communication technologies used in open distance education system in general and in BRAOU in particular,

- to find out the process of planning and management of the technologies for distance teaching of BRAOU,

- to assess the impact of the technologies on the distance learning of BRAOU students, and

- to make suggestions, on the basis of the study, for effective and efficient management of technology in BRAOU.

This study adopted descriptive method of research, which is widely used in educational research. Experiences, opinions and perceptions of 510 undergraduates students, 184 postgraduates, 110 academic counselors and 52 study center Heads are collected through separate questioners. Important results of survey are briefly stated here.

Keywords: Distance education, information and communication technologies, selection of media and management.

\section{INTRODUCTION}

In 1982 the establishment of Dr. B. R. Ambedkar Open University (BRAOU), the first distance teaching university in India, was a great educational event. It heralded a new era in India's higher education. It set in a new educational trend in adult education. It started a new chapter in the history of India's distance higher education. It paved the way for founding of 13 other Open Universities in India. 
The Expert Committee on the Establishment of BRAOU strongly suggested the use of multimedia for instructional purpose. The Expert Committee recommended TV and Radio broadcasts as well as audio-video programmes to be used as an integral part of the instruction 'to enrich support, illuminate demonstrate or otherwise strengthen the learning experiences of courses'. Following the Expert Committee Report, the University designed and evolved a multimedia instructional system comprising:

- Course units - these are specially structured course books which from the core of the teaching material.

- TV, Radio and Teleconferencing programmes - these are normally relatively less important supplement to the course units, although they form part of the university's teaching.

- Programmes on audio tapes - these are either broadcast on AIR or independently produced for presentation at study centers.

- Programmes on video tapes - these are specially developed for presentation at the study centers for students, academic counselors and coordinators.

- Face-to-face tutorial sessions at study centers.

- Counseling services to students by the coordinators, academic counselors and the academic heads of host institutions of study centers.

- Course assignments as an instrument of teaching and continuous assessment.

- Summer and winter schools and intensive tutorial programmes.

- Project works.

- Practical experiences for science courses at select study centers and Headquarters

- Term end examinations

BRAOU is fortunate to get time on AIR for broadcasting its programmes almost from the beginning of the offer of academic programmes on four days a week (Monday, Wednesday, Thursday and Friday), six 30 minutes slots (7:15-7:45 Hours and 22:30-23:00 Hours) on Hyderabad - "B" station with short-wave support for Statewide coverage. All the programmes broadcasted on radio are also put on audio tapes and are made available at the Study Centers for the benefit of students and counsellors. Those who miss radio broadcasts would go to the Study Centers and hear the programmes.

Besides the broadcasting programmes, a number of additional audio programmes are also produced on cassettes and are made available at the Study Centers. The University could not get any slot on Doordarshan for many years. Without waiting for the time for telecasts, the University produced video programmes and their tapes are made available at all Study Centers for the benefit of students and academic counsellors. Telecasts began in 1999 from Monday to Friday between 5:30 a.m., and 6:00 a.m., through public television (Doordarshan).

Later, telecasts began on 'Mana TV' (State specific Educational Network) from Monday to Friday between 8:30 a.m., and 9:30 a.m., with repetition between 4:30 p.m., and 5:30 p.m. Teleconferencing also began on Sundays between 2:00 p.m., and 3:00 p.m., on Doordarshan also later on 'Mana TV'.

BRAOU established its Audi-Visual Production and Research Centre (AVPRC) in 1986 as part of the Material Production Directorate. The Centre became a separate unit headed by a Director in 1993, with the following major objectives: 
- to produce audio and video educational programmes.

- to organize transmission of educational programmes over radio and television.

- to conduct training and academic programmes in communication.

- to undertake research in the field of educational technology as applied to distance education.

Programme-Wise and Year-Wise Production of Radio, Audio and Video Lessons Produced by AVPRC

\begin{tabular}{|c|c|c|c|c|c|c|c|c|c|c|c|c|c|c|c|c|c|c|}
\hline \multirow[t]{2}{*}{$\begin{array}{c}\text { Academic } \\
\text { Year }\end{array}$} & \multicolumn{3}{|c|}{ Arts } & \multicolumn{3}{|c|}{$\begin{array}{c}\text { Social } \\
\text { Sciences }\end{array}$} & \multicolumn{3}{|c|}{ Science } & \multicolumn{3}{|c|}{ Commerce } & \multicolumn{3}{|c|}{ General } & \multicolumn{3}{|c|}{ Total } \\
\hline & $\mathbf{R}$ & $\mathbf{A}$ & $\mathbf{V}$ & $\mathbf{R}$ & A & $\mathbf{V}$ & $\mathbf{R}$ & $\mathbf{A}$ & V & $\mathbf{R}$ & A & V & $\mathbf{R}$ & $\mathbf{A}$ & V & $\mathbf{R}$ & $\mathbf{A}$ & $\mathbf{V}$ \\
\hline $1983-84$ & 61 & - & 03 & 32 & - & - & 34 & - & - & - & - & - & - & - & - & 127 & - & 03 \\
\hline 1984-85 & 53 & - & 07 & 85 & 14 & 11 & 58 & 08 & 03 & 32 & - & 03 & - & - & - & 228 & 22 & 24 \\
\hline $1985-86$ & 99 & 11 & 03 & 72 & 03 & 20 & 119 & 06 & 09 & 72 & 04 & 04 & 06 & - & - & 368 & 24 & 36 \\
\hline $1986-87$ & 54 & 27 & 04 & 36 & 15 & 09 & 63 & 08 & 06 & 68 & 04 & 05 & - & - & - & 221 & 54 & 24 \\
\hline $1987-88$ & 33 & 17 & 04 & 46 & 23 & 01 & 26 & 09 & 03 & 24 & 06 & 03 & - & - & - & 129 & 55 & 11 \\
\hline 1988-89 & 09 & 13 & 04 & 18 & 15 & 04 & 17 & 02 & - & $09:$ & 13 & 01 & 06 & - & - & 59 & 43 & 09 \\
\hline $1989-90$ & - & 06 & 02 & 20 & 07 & 02 & 09 & 01 & - & 03 & 08 & 02 & - & - & 02 & 32 & 22 & 08 \\
\hline 1990-91 & 09 & 04 & - & 14 & 01 & 03 & 02 & - & - & 04 & 03 & - & - & - & 04 & 29 & 08 & 07 \\
\hline 1991-92 & 10 & 04 & - & 06 & - & 03 & - & - & 01 & - & - & - & 06 & - & 06 & 22 & 04 & 10 \\
\hline $1992-93$ & 10 & - & - & - & - & 07 & 01 & - & 02 & 01 & - & - & 13 & - & 09 & 25 & - & 18 \\
\hline 1993-94 & 08 & - & 05 & 46 & - & 07 & 38 & - & 12 & 52 & - & - & - & - & 18 & 144 & - & 42 \\
\hline 1994-95 & - & - & - & 04 & - & - & 05 & - & - & 09 & - & - & - & - & - & 18 & - & - \\
\hline 1995-96 & 03 & - & - & 03 & 01 & - & 04 & - & - & 02 & 01 & - & - & - & - & 12 & 02 & - \\
\hline 1996-97 & 14 & - & - & 15 & 07 & - & 21 & - & - & 16 & - & - & - & - & - & 66 & 07 & - \\
\hline $1997-98$ & 03 & - & 07 & 54 & 01 & 06 & 08 & - & 03 & 06 & - & - & - & - & 03 & 71 & 01 & 19 \\
\hline 1998-99 & 04 & 01 & - & 34 & 01 & - & 05 & - & - & 08 & - & - & - & - & - & 51 & 02 & - \\
\hline 1999-00 & 06 & - & 20 & 09 & - & 34 & 02 & - & 32 & - & - & 11 & - & - & 03 & 17 & - & 100 \\
\hline 2000-01 & 20 & - & 01 & - & - & 02 & 09 & - & 05 & - & - & 04 & - & - & - & 29 & - & 12 \\
\hline 2001-02 & 09 & - & 09 & 21 & - & 24 & 09 & - & 16 & 11 & - & 16 & - & - & 07 & 50 & - & 72 \\
\hline 2002-03 & 09 & - & 20 & 45 & - & 34 & 12 & - & 27 & 22 & - & 29 & 19 & - & 01 & 107 & - & 111 \\
\hline 2003-04 & 15 & - & 22 & 29 & - & 15 & 09 & - & 12 & 07 & - & 10 & 01 & - & 02 & 61 & - & 61 \\
\hline 2004-05 & 27 & - & 17 & 31 & - & 24 & 16 & - & 29 & 19 & - & 17 & - & - & 01 & 93 & - & 88 \\
\hline 2005-06 & 05 & - & 33 & 32 & - & 46 & 18 & - & 29 & 03 & - & 34 & - & - & 06 & 58 & - & 148 \\
\hline 2006-07 & 10 & - & 16 & 17 & - & 33 & 10 & - & 08 & 08 & - & 22 & - & - & - & 45 & - & 79 \\
\hline Total & 471 & 83 & 177 & 669 & 88 & 285 & 495 & 34 & 197 & 376 & 39 & 160 & 51 & - & 62 & 2062 & 244 & 881 \\
\hline
\end{tabular}


Production of Tele Lessons from 1999 to December 2007 by AVPRC

\begin{tabular}{|c|c|c|c|c|c|c|c|c|c|c|c|}
\hline & 1999 & 2000 & 2001 & 2002 & 2003 & 2004 & 2005 & 2006 & 2007 & Total & \\
\hline $\mathbf{A}$ & Faculty of Arts & & & & & & & & & & \\
\hline 1 & English (FC) & 1 & 1 & 6 & 0 & 6 & 1 & 1 & 0 & 0 & 16 \\
\hline 2 & English (UG) & 1 & 2 & 3 & $\mathbf{0}$ & 1 & 3 & 2 & $\mathbf{0}$ & 3 & 15 \\
\hline 3 & English (PG) & $\mathbf{0}$ & $\mathbf{0}$ & $\mathbf{0}$ & 0 & 0 & 2 & 4 & 4 & 3 & 13 \\
\hline 4 & Telugu (FC) & $\mathbf{0}$ & 3 & 2 & 0 & 0 & 0 & 0 & 2 & 0 & 7 \\
\hline 5 & Telugu & 1 & 5 & 2 & 1 & 3 & 8 & 5 & 5 & 1 & 31 \\
\hline 6 & Hindi (FC) & 0 & 3 & $\mathbf{0}$ & 1 & 2 & 0 & 1 & 2 & 1 & 10 \\
\hline 7 & Hindi & 1 & 3 & 0 & 1 & 0 & 6 & 5 & 5 & $\mathbf{0}$ & 21 \\
\hline 8 & Urdu (FC) & 1 & 1 & 4 & 3 & 1 & 2 & 1 & 2 & 0 & 15 \\
\hline 9 & Urdu & 1 & 3 & 3 & 4 & 1 & 3 & 3 & 5 & 2 & 25 \\
\hline 10 & $\begin{array}{l}\text { Media Writing } \\
\text { in } \\
\text { Teulgu (PGD) }\end{array}$ & 2 & 0 & 0 & 5 & 0 & 2 & 2 & 3 & 0 & 14 \\
\hline Total & 8 & 21 & 20 & 15 & 14 & 27 & 24 & 28 & 10 & 167 & \\
\hline B & $\begin{array}{l}\text { Faculty of } \\
\text { Commerce }\end{array}$ & & & & & & & & & & \\
\hline 1 & Commerce & 2 & 12 & 13 & 1 & 3 & 8 & 13 & 12 & 3 & 67 \\
\hline 2 & Management & 2 & 9 & 23 & 13 & 8 & 4 & 10 & 22 & 3 & 94 \\
\hline Total & 4 & 21 & 36 & 14 & 11 & 12 & 23 & 34 & 6 & 161 & \\
\hline C & $\begin{array}{l}\text { Faculty of } \\
\text { Science }\end{array}$ & & & & & & & & & & \\
\hline 1 & $\begin{array}{l}\text { Science \& } \\
\text { Technology } \\
\text { (FC) }\end{array}$ & 1 & 3 & 2 & 2 & 3 & 0 & 2 & 5 & 0 & 18 \\
\hline 2 & Chemistry & 3 & 5 & 4 & 5 & 2 & 0 & 5 & 3 & 0 & 27 \\
\hline 3 & $\begin{array}{l}\text { Chemistry } \\
\text { (DS) }\end{array}$ & & & & & & 4 & 2 & 1 & 0 & 7 \\
\hline 4 & Physics & 2 & 3 & 1 & 4 & 3 & 6 & 3 & 3 & 1 & 26 \\
\hline 5 & Botany & 4 & 1 & 3 & 2 & 0 & 3 & 3 & 3 & 0 & 19 \\
\hline 6 & Zoology & 3 & 5 & 4 & 3 & 1 & 3 & 5 & 1 & 0 & 25 \\
\hline 7 & $\begin{array}{l}\text { Mathematics } \\
\text { (UG) }\end{array}$ & 2 & 1 & 1 & 1 & 1 & 1 & 4 & 2 & 1 & 14 \\
\hline 8 & $\begin{array}{l}\text { Mathematics } \\
\text { (PG) }\end{array}$ & 1 & 6 & 2 & 1 & 0 & 3 & 5 & 1 & 0 & 19 \\
\hline 9 & Geology & 1 & 3 & 2 & 1 & 2 & 3 & 2 & 1 & 1 & 16 \\
\hline Total & 17 & 27 & 19 & 19 & 12 & 23 & 31 & 20 & 3 & 171 & \\
\hline D & $\begin{array}{l}\text { Faculty of } \\
\text { Social Science }\end{array}$ & & & & & & & & & & \\
\hline 1 & $\begin{array}{l}\text { Social Science } \\
\text { (FC) }\end{array}$ & 0 & 1 & 1 & 0 & 5 & 0 & 1 & 2 & 1 & 11 \\
\hline 2 & $\begin{array}{l}\text { Economics } \\
\text { (UG) }\end{array}$ & 1 & 3 & 3 & 4 & 2 & 3 & 1 & 1 & 3 & 21 \\
\hline 3 & $\begin{array}{l}\text { Economics } \\
\text { (PG) }\end{array}$ & 0 & 1 & 1 & 0 & 2 & 2 & 2 & 5 & 3 & 16 \\
\hline 4 & History (UG) & 1 & 2 & 1 & 2 & 0 & 2 & 3 & 4 & 2 & 17 \\
\hline 5 & History (PG) & 1 & 3 & 1 & 1 & 0 & 2 & 3 & 4 & 2 & 17 \\
\hline 6 & $\begin{array}{l}\text { Political } \\
\text { Science (UG) }\end{array}$ & 2 & 5 & 3 & 0 & 3 & 1 & 3 & 4 & 3 & 24 \\
\hline 7 & $\begin{array}{l}\text { Political } \\
\text { Science (PG) }\end{array}$ & 0 & 1 & 2 & 0 & 1 & 1 & 2 & 4 & 2 & 13 \\
\hline
\end{tabular}




\begin{tabular}{|c|c|c|c|c|c|c|c|c|c|c|c|}
\hline & 1999 & 2000 & 2001 & 2002 & 2003 & 2004 & 2005 & 2006 & 2007 & Total & \\
\hline 8 & $\begin{array}{l}\text { Public } \\
\text { Administration } \\
\text { (UG) }\end{array}$ & 2 & 5 & 2 & 2 & 2 & 2 & 3 & 3 & 2 & 23 \\
\hline 9 & $\begin{array}{l}\text { Public } \\
\text { Administration } \\
\text { (PG) }\end{array}$ & 1 & 4 & 2 & 2 & 3 & 1 & 2 & 3 & 2 & 20 \\
\hline 10 & $\begin{array}{l}\text { Sociology } \\
\text { (UG) }\end{array}$ & 1 & 4 & 1 & 2 & 2 & $\mathbf{0}$ & 2 & 3 & 0 & 15 \\
\hline 11 & Sociology (PG) & $\mathbf{0}$ & $\mathbf{0}$ & $\mathbf{0}$ & $\mathbf{0}$ & 1 & 2 & 3 & 3 & 1 & 10 \\
\hline 12 & $\begin{array}{l}\text { Library } \\
\text { Science (BLISc) }\end{array}$ & 1 & 2 & 1 & 2 & 1 & 2 & 2 & 4 & 1 & 16 \\
\hline 13 & $\begin{array}{l}\text { Library } \\
\text { Science (MLISc) }\end{array}$ & 2 & 1 & 4 & 2 & 3 & 2 & 4 & 7 & 2 & 27 \\
\hline 14 & $\begin{array}{l}\text { Public } \\
\text { Relations (BPR) }\end{array}$ & 1 & 2 & 6 & 1 & 0 & 0 & 3 & 2 & 1 & 19 \\
\hline 15 & $\begin{array}{l}\text { Human } \\
\text { Rights (PGD) }\end{array}$ & 0 & 0 & $\mathbf{0}$ & 3 & $\mathbf{0}$ & 0 & 0 & 1 & 0 & 4 \\
\hline 16 & $\begin{array}{l}\text { Women } \\
\text { Studies (PGD) }\end{array}$ & $\mathbf{0}$ & $\mathbf{0}$ & 0 & $\mathbf{0}$ & 0 & 3 & 1 & 0 & $\mathbf{0}$ & 4 \\
\hline Total & 13 & 34 & 28 & 21 & 25 & 23 & 35 & 50 & 25 & 257 & \\
\hline $\mathbf{E}$ & General & & & & & & & & & & \\
\hline 1 & $\begin{array}{l}\text { Student } \\
\text { Services }\end{array}$ & 3 & 4 & 3 & 7 & 14 & 0 & 5 & 2 & 1 & 39 \\
\hline 2 & Training & 0 & 0 & 0 & 0 & 6 & 0 & 0 & 0 & 0 & 6 \\
\hline Total & 3 & 4 & 3 & 7 & 20 & 0 & 5 & 2 & 1 & 45 & \\
\hline $\begin{array}{l}\text { Grand } \\
\text { Total }\end{array}$ & 45 & 107 & 106 & 76 & 82 & 85 & 118 & 134 & 45 & 801 & \\
\hline
\end{tabular}

Faculty-wise Teleconferencing Programmes organized by AVPRC through DD-Saptagiri from 05-12-1999 to 26-08-2007 and Mana TV (Ku-band) from 26-08-2002 to 30-04-2006

\begin{tabular}{|c|c|c|c|}
\hline $\begin{array}{l}\text { S. } \\
\text { No }\end{array}$ & Subject & $\begin{array}{c}\text { No. of Programmes } \\
\text { through } \\
\text { DD-Saptagiri }\end{array}$ & $\begin{array}{c}\text { No. of programmes } \\
\text { through } \\
\text { Mana TV (Ku-band) }\end{array}$ \\
\hline & Faculty of Social Sciences & & \\
\hline 1 & Economics & 16 & 16 \\
\hline 2 & History & 14 & 10 \\
\hline 3 & Political Science & 12 & 11 \\
\hline 4 & Public Administration & 15 & 10 \\
\hline 5 & Sociology & 13 & 04 \\
\hline 6 & Social Science (FC) & 09 & 06 \\
\hline 7 & Public Relations & 10 & 09 \\
\hline 8 & Library Science & 19 & 27 \\
\hline 9 & Human Rights & 03 & 01 \\
\hline \multirow[t]{3}{*}{10} & Women Studies & 00 & 01 \\
\hline & Sub-Total & 111 & 95 \\
\hline & Faculty of Arts & & \\
\hline 1 & Telugu & 20 & 09 \\
\hline 2 & English & 14 & 14 \\
\hline 3 & Hindi & 15 & 14 \\
\hline 4 & Urdu & 17 & 10 \\
\hline \multirow[t]{3}{*}{5} & Media Writing in Telugu & 03 & 04 \\
\hline & Sub-Total & 69 & 51 \\
\hline & General Programmes & & \\
\hline 1 & Student support services/Trainings & 82 & 100 \\
\hline
\end{tabular}




\begin{tabular}{|c|c|c|c|}
\hline $\begin{array}{l}\text { S. } \\
\text { No }\end{array}$ & Subject & $\begin{array}{c}\text { No. of Programmes } \\
\text { through } \\
\text { DD-Saptagiri }\end{array}$ & $\begin{array}{c}\text { No. of programmes } \\
\text { through } \\
\text { Mana TV (Ku-band) }\end{array}$ \\
\hline & Faculty of Sciences & & \\
\hline 1 & Chemistry & 13 & 15 \\
\hline 2 & Physics & 10 & 13 \\
\hline 3 & Botany & 09 & 14 \\
\hline 4 & Zoology & 13 & 13 \\
\hline 5 & Mathematics & 07 & 16 \\
\hline 6 & Geology & 07 & 10 \\
\hline 7 & Science \& Technology (FC) & 13 & 08 \\
\hline 8 & General Sciences & 02 & 00 \\
\hline 9 & Information Technology (FC) & 01 & 00 \\
\hline \multirow[t]{3}{*}{10} & Certificate in Computers & 01 & 00 \\
\hline & Sub-Total & 76 & 89 \\
\hline & Faculty of Commerce & & \\
\hline 1 & Commerce & 32 & 33 \\
\hline 2 & Management & 29 & 38 \\
\hline \multirow[t]{2}{*}{3} & Hotel Management & 02 & 00 \\
\hline & Sub-Total & 63 & 71 \\
\hline $\begin{array}{l}\text { Grand } \\
\text { Total }\end{array}$ & 325 & 406 & \\
\hline
\end{tabular}

\section{USE OF TECHNOLOGY BY BRAOU}

\section{Radio Lessons}

\begin{tabular}{|l|l|l|}
\multicolumn{1}{|c|}{ Station } & \multicolumn{1}{c|}{ Timings (Spot) } & \multicolumn{1}{c|}{ Schedules (Slot) } \\
\hline Hyderabad B & $\mathbf{0 7 . 1 5} \mathbf{~ a m ~ - ~ 0 7 . 4 5 ~ a m ~}$ & Monday, Wednesday, Friday \\
\hline Hyderabad B & $\mathbf{1 0 . 3 0 ~} \mathbf{~ p m - 1 1 . 0 0 ~} \mathbf{~ p m}$ & Monday, Thursday, Friday \\
\hline
\end{tabular}

\section{Radio Phone-in-Programmes}

\begin{tabular}{|l|l|l|}
\multicolumn{1}{|c|}{ Station } & \multicolumn{1}{c}{ Timings (Spot) } & \multicolumn{1}{c}{ Schedules (Slot) } \\
\hline Hyderabad & $4.00 \mathrm{pm}-\mathbf{5 . 0 0} \mathrm{pm}$ & Every $\mathbf{4}^{\text {th }}$ Sunday \\
\hline
\end{tabular}

\section{Tele lessons}

\begin{tabular}{|c|c|c|}
\hline Channel & Time & Programme/Transmission \\
\hline DD Saptagiri & $05.30 \mathrm{am}-06.00 \mathrm{am}$ & $\begin{array}{c}\text { Monday, Tuesday, Wednesday, } \\
\text { Thursday, Friday }\end{array}$ \\
\hline MANA TV & $09.30 \mathrm{am}-10.30 \mathrm{am}$ & $\begin{array}{c}\text { Monday, Tuesday, Wednesday, } \\
\text { Thursday, Friday }\end{array}$ \\
\hline $\begin{array}{l}\text { MANA TV } \\
\text { (Repeat) }\end{array}$ & 04.00 pm - 05.00 pm & $\begin{array}{c}\text { Monday, Tuesday, Wednesday, } \\
\text { Thursday, Friday }\end{array}$ \\
\hline
\end{tabular}

\section{Teleconferences}

\begin{tabular}{|c|c|c|}
\hline Channel & Time & Programme/Transmission \\
\hline DD Saptagiri & 02.00 pm -03.00 pm & Every Sunday \\
\hline \multirow[t]{3}{*}{ MANA TV } & $10.00 \mathrm{am}-11.00 \mathrm{am}$ & Every Sunday \\
\hline & $11.15 \mathrm{am}-12.15 \mathrm{pm}$ & \\
\hline & $12.30 \mathrm{pm}-01.30 \mathrm{pm}$ & \\
\hline
\end{tabular}




\section{WHY THIS STUDY?}

The survey of literature on the role of technology in BRAOU reveals that comprehensive and indepth research has not yet been conducted. This survey highlights the wide gap in the research literature on the role of technology in BRAOU. Institutional research is totally absent on the subject.

Many of the technologies used in BRAOU are not studied by internal faculty members, Audio Visual Production and Research Centre staff or by others with the support from the promotional organizations in distance education such as DEC, COL, AAOU, UGC, etc. An attempt is made by the authors to study the role of technologies in BRAOU with particular reference to radio lessons, radio phone-in-programmes, audio programmes on cassettes, tele-lessons, teleconference and video programmes on cassettes. How these technologies are managed for distance teaching and learning is the main thrust of the study. This study aims at partly filling the gap in research literature on the role of multiple media/technologies in BRAOU, existing over 25 years.

\section{OBJECTIVES}

The general objects these research studies are:

- to identify the information and communication technologies used in open distance education system in general and in BRAOU in particular,

- to find out the process of planning and management of the technologies for distance teaching of BRAOU,

- to assess the impact of the technologies on the distance learning of BRAOU students, and

- to make suggestions, on the basis of the study, for effective and efficient management of technology in BRAOU.

The specific objectives are:

- to identify the technologies utilized for instruction and administration purposes of BRAOU,

- to highlight the merits and demerits of different technologies in distance teaching and learning processes,

- to study the process of planning, designing and production of audio and video technologies in BRAOU.

- to study the pattern of use of technologies by learners of BRAOU,

- to study the experiences, opinions and perceptions of academic staff, student support providers and academic counselors of BRAOU on the production and use of different communication technologies by students of BRAOU,

- to examine the organizational requirements for proposed effective operation of the educational media production and for meaningful use of educational media by students of BRAOU,

- to describe the bases for the selection of media and for the combination of media in BRAOU,

- to offer suggestions on the basis of the findings of the study, for effective and efficient use of educational communication technologies or media for distance teaching and learning of BRAOU 


\section{RESEARCH METHODOLOGY}

This study adopted descriptive method of research, which is widely used in educational research.

This method helps to explain the phenomena in terms of conditions that exist, opinions that are held by students and teachers, processes that are in operation, effects that are evident and trends that are developing.

Through descriptive survey, experiences, opinions, perceptions and suggestions for the improvement of the use of technologies are obtained from Students, Academic Staff, Academic Counselors and Study Center Heads. The student sample covered 184 postgraduate students, 510 undergraduate students, 33 Academic Staff, 110 Academic Counselors and 52 Study Centre Heads as shown below. Different structured questionnaires, partly open and partly closed, are used for the all the four categories of respondents.

Sample Size

\begin{tabular}{|l|c|c|c|c|c|}
\hline \multicolumn{1}{|c|}{ Region } & $\begin{array}{c}\text { No. of Study } \\
\text { Centres }\end{array}$ & $\begin{array}{c}\text { No. of } \\
\text { Students }\end{array}$ & $\begin{array}{c}\text { No of Academic } \\
\text { Counsellors }\end{array}$ & $\begin{array}{c}\text { No. of Study } \\
\text { Centre Heads }\end{array}$ & $\begin{array}{c}\text { No. of Academic } \\
\text { Staff }\end{array}$ \\
\hline I Twin Cities & 6 & 260 & 36 & & \\
\hline II Telangana & 4 & 133 & 24 & & \\
\hline III Rayalseema & 4 & 158 & 24 & & \\
\hline IV Costal Andhra & 4 & 143 & 26 & & \\
\hline Total & 18 & 694 & 110 & 52 & 33 \\
\hline
\end{tabular}

\section{SUMMARY OF SURVEY RESULTS}

Experiences, opinions and perceptions of 510 undergraduates students, 184 postgraduates, 110 academic counselors and 52 study center Heads are collected through separate questioners. Here important results of survey are briefly summarized. This summary serves as an index to the significant survey results.

Students' Perception of Differences between Regular Face-to-Face Study and Distance Study Majority of students do not take interest to clearly understand the difference between conventional and distance modes of study. Only a small number of students could perceive the role of non-print communication technologies in distance education and their absence in regular full time face-to-face campus based education. $18 \%$ of UG student respondents and 29 $\%$ of PG student respondents stated 'non-print technology such as radio lessons, television lessons, audio and video cassettes are provided to distance students' as the difference between regular and distance education. One major difference identified by almost all the student respondents is the 'non-requirement of attendance at class rooms'.

\section{Students' Satisfaction with the Printed Course Materials Supplied by the University}

Students are by and large are happy with the printed course materials supplied to them by the University. For half of PG students and two thirds of UG students, printed course materials are self-instructional. For one third of PG students and a small number of UG students, the printed materials are not self-instructional form. Several features of non-self instructional nature of print materials are mentioned by those who said that printed materials are not selfinstructional. 
Non-Utilization of Non-Print technologies by Students

Bulk of students used only print technology. 451 students of 510 sampled UG students, and 165 students out of 184 PG students used print technology in their learning. Surprisingly, no student uses any non-print technology in the study.

Reasons for non-utilization of non-print media stated by students, academic staff, academic counselors and study center Heads are mostly the same.

The main reasons include:

- Self-sufficiency of print materials in studies. Contents of radio and television programmes are already in the printed materials.

- Non-compulsory nature of electronic media in studies.

- Exclusion of radio and television programmes for examination purpose

- Lack of electronic educational media habit among students.

- Limited coverage of course topics in radio and television programmes.

- lack of advance information on media programmes to students.

- Disinterest of academic counselors, study center Heads in motivating students towards the use of electronic media.

- Lack of equipment and facilities at study centers for radio and television programmes

- Regular college and university students do not use radio and television programmes.

Non use of Handbooks for Academic Counsellors and Managers of Study Centers Handbooks for Academic Counsellors and Managers of study centres are not followed by most of the academic counsellors and study centre Heads.

\section{Students' Limited Awareness of Media Programmes}

Awareness of radio broadcasts telecasts, radio phone-in-programmes, teleconferences among students is very limited. Most of the students are not aware of the multiple media based instructional system of the University.

The limited number students who are aware of media programmed do not use them due to;

- lack of time,

- non-availability of programme schedules,

- self-sufficiency of printed materials,

- non-availability electronic gadgets, and

- non-suitability of programme timings.

\section{Limited Impact of MANA TV}

For viewing MANA TV programmes, special reception facilities are needed. Most of the study centres do not have such facilities. Thus, literally MANA TV programmes have impact on students. Moreover, MANA TV repeats programmes which are already telecast by Doordarshan.

Non-Functioning of Certain AV Equipment Provided by Study Centers

In the early years of the University, audio and video cassettes and play equipment for them were provided. Later, they became defective and non cared for. No new equipment is substituted. Thus most of study centers are left with no equipment. 
Formats of Television Programmes

Television programmes are mostly in lecture format, which are not of interest to students.

Absence of Scientific Bases for Decision Making on Media Components of Courses

There seems to be no scientific basis for selection of electronic media components of courses. No true course team approach is followed resulting in adhocism.

Limited Manpower of AVPRC

AVPRC has limited manpower (Production Staff) and do not go for outdoor shooting.

Lack of Interaction between Academic Staff and Production Staff of the University

Continuous and meaningful interaction between academic staff and production staff is lacking. Academics go by their own ideas and do not appreciate the well-established principles of media production.

No Feedback from Students on Their Media Use

No feedback on the quality and use of electronic media is obtained from students. Feedback helps in setting things right.

Lack of Training on Course Preparation

Academic staff who design non-print media mostly lack training in the role of technology in distance teaching.

Not Enough Financial Resources for AVPRC

Besides limited human resources, a limited financial resource for AVPRC tells on the quantity and quality of media production. Efforts are not made increase the financial resources of AVPRC.

Lack of Equipment and Facilities at Study Centers for Radio and Television Programmes

The survey revealed the absence of appropriate equipment and facilities in most of the study centers. Experiences and opinions of students, academic counsellors and study center Heads on this aspect are mostly similar.

Suggestions for Effective and Efficient Use of Technology.

Suggestions from students, academic staff, academic counsellors and study center Heads, for effective and efficient management of technology in the University include:

- Induction meetings for new students at study centers on the multiple media based teaching-learning of the Open University.

- Highlighting the usefulness of media programmes for students by academic counsellors and study center staff.

- Transforming all radio and television programmes into cassettes/tapes/discs and placing them at major study centers.

- Providing the necessary equipment and facilities at most of the study centers for radio and television programmes.

- Proper training for academic counsellors, on integrating counseling sessions with electronic media contents.

- Special sessions at study centers on Sundays and other days for recorded radio and television programmes.

- Getting feedback from students and counselors and evaluating it for bettering the system.

- Making available IGNOU and other Open Universities' media products at major study centers for the use of study by students 


\section{NON-UTILIZATION OF ELECTRONIC MEDIA IN BRAOU}

On the issue of non-utilization of electronic media by students experiences and opinions are collected from a sample of students, academic staff members, academic counsellors and study center Heads. Students gave 10 reasons, academic staff members gave 14 reasons and academic counsellors gave 7 reasons. Study center Heads gave reasons similar to those of counsellors.

The significant common reasons indicated by all the four categories are the following:

- Printed course materials supplied by the University are self-sufficient and selfdirecting for student study.

- Contents of electronic media programmes are already in the printed course materials.

- Electronic media programmes are not made compulsory for students by the University. Examinations do not include questions on media programmes.

- Media programmes cover very few aspects of very few course subjects.

- Student's regular colleges and Universities do not use electronic media. Then why for distance students?

- Media programme schedules are not available in advance to students.

- Counseling sessions are held at study centers on Sundays. Some media programmes are also on Sundays. Due to the clash, students cannot use media programmes.

- Most of the academic counselors and study center Heads do not take interest in motivating students towards the use of non-print media

- Many $1^{\text {st }}$ year UG students develop drop out tendency and are not bothered about print and non-print media.

- Broadcast/telecast timings are not suitable to students.

- Most of the study centers do not have proper equipment and facilities for presentation of audio and video programmes on cassettes.

- MANA TV reception facilities are very limited in view of their technical nonavailability.

- Most of the students do not have educational media habit.

- Most of the non-print media programmes are simple lectures and lack visuals and hence do not create appeal.

- All radio and television broadcasts are not available at study centers on cassettes and tapes. Hence, even a small number of interested students cannot have access to media programmes.

The University should seriously consider the responses of the students, counselors, and study center Heads and academics of the University. The University should take critical view of the experiences, opinions and perceptions of all the players in the field.

\section{SUGGESTIONS FOR EFFECTIVE AND EFFICIENT USE OF TECHNOLOGY}

While assessing the role of technology in its academic and administration operations, the University should consider the various suggestions made by academic staff, academic counselors' and study center Heads. Common suggestions of significance and relevance 
offered by the key managers of the University are following:

- Induction meetings for newly admitted students every year should be held at study centers for orienting students on the useful of technology for student learning

- Student Handbooks for all course should include advantages of print and nonprint technologies to students in their learning

- Academic counselors and study center Heads should motivate the students towards the use of non-print electronic media programmes

- All radio broadcasts and television broadcasts of the University should be put on cassettes/tapes/CDs/DVDs, and be made available to students at study centers

- Maximum number of study center should be equipped with the gadgets and services necessary for presentation of electronic media programmes. In view of the increasing role of technology in distance education, the following equipment needed to be placed at maximum number of study centers of the University:

- Telephone

- Telephone with STD facility

- Mobile Phone

- Radio

- Tape recorder

- Radio cum tape recorder

- TV set
- TV set with cable connection

- TV with DTH

- TV with MANA TV reception facility

- VCP/VCD/DVD player

- Computer with Internet facility

- COMBO Drive
- Scanner

- Audio cassettes

- Video cassettes

- Fax Machine

- Xerox Machine

- Overhead/LCD Projector

- IPod

- On Sundays and other days, study center should conduct additional sessions only for presentation of audio and video programmes

- Media production facilities at the University headquarters should increase in terms of technical personnel and modern equipment

- Interactive between academics, production staff, student support planners should be more and continuous

- Rational decision making on media components of courses should occur.

- Coordination between AIR, Doordarshan and University on the role of media should occur.

- Training in media planning and production for academics, production staff should be periodically organized with the help of EMPC, AIR, Doordarshan, MANA TV

- University should appoint a high level technical committee with media specialists and representatives of Akashvani and Doordarshan to study the University's management of multiple media based distance education system and be benefited by its suggestions. 


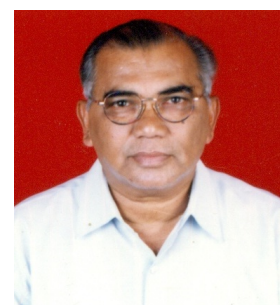

Dr. P. SATYANARAYANA was a consultant to Educational Consultants India Limited for IGNOU Project. After the establishment of IGNOU he was with it as Joint Director and later as Regional Director. His works include Distance Education: Different Dimensions, Open and Distance Education Research, Indian Open University System, etc. He participated in several national and international workshops and seminars conducted by UGC, ICDE, AAOU, UNESCO etc.,

Dr. P. SATYANARAYANA Former Regional Director

Indira Gandhi National Open University

C-10/1, Kakatiya Nagar, Habsiguda,

Hyderabad 500 007, INDIA

Email: satyanarayana1938@rediffmail.com

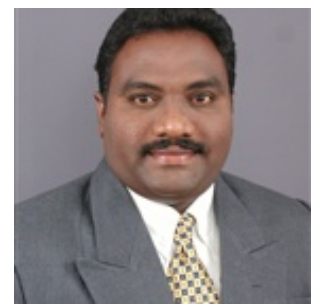

Emmanuel DK MEDURI, Ph.D is a Professor of Management at Teegala Krishna Reddy Engineering College, Hyderabad. He represents Global Universities in Distance Education, Rome in India. He specialized in management of ICT in distance education. He presented papers at national and international conferences organized by FACCI, AIMA, IDEA, AIOU, and ICDE. He also worked as Consultant to Prof. G. Ram Reddy Research Academy in Distance Education, Dr. B.R. Ambedkar Open University. His works include E-Learning Wave in India, Technology Mediated Distance Education.

Dr. Emmanuel DK MEDURİ, Ph.D.

Prof. of Mgt., Dept. of MBA

Teegala Krishna Reddy Engineering College

Medbowli, Meerpet, Hyderabad 500097 INDIA

Mobile: 9133292991

Email: emanphd@gmail.com

\section{REFERENCES}

Bansal, K and Chaudhary, S. S. (1999). Interactive Audio for Supporting Distance Education: An Evaluation Study. Indian Journal of Open Learning, 8 (1).

Bates, A. W. (2005). Technology, E-Learning and Distance Education. London: Routledge.

Chaudhary, S. V. S and Panda, S (2005). Educational Television and Teleconferencing. In Reddi, U.V., and Mishra, S. (Eds), Educational Media in Asia: Perspectives on Distance Education.

Vencour: COL.

Mishra, S. (2005). Audio, Radio and Interactive Radio. In Reddi, V.U., and Mishra, S. (Eds), Educational Media in Asia : Perspectives on Distance Education. Vencouver : COL.

Prasad, V and Venkaiah V. (2005). India's First Open University: Experience of Two Decades. Hyderabad: GRADE, BRAOU. 
Ranga Rao, C. V. (2006). Technology Enabled Learner Services in Dr. BRAOU: Promise and Performance, in Spectrum: Research Contributions of India's First Open University. Hyderabad: GRADE, BRAOU.

Satyanarayana, P and Emmanuel DK (2007): Use of ICTs in Distance Education. In Emerging Trends in the Use of ICTs. Hyderabad: MGNIRSA.

Sesharatnam, C. (2002). India's First Open University: Two Decades Journey, Hyderabad: Book Links Corporation.

Venkaiah, V. (2005). Educational Media in Dr. BRAOU with special reference to Teleconferencing. In Educational Media in Asia : Perspectives on Distance Education. Vencouver: COL. 